УДК 355.018-057.36(477)АТО:159.942

DOI https://doi.org/10.32782/humanitas/2021.5.3

\title{
Аліна ДУЛЯ
}

викладач кафедри соиіальної педагогіки та соціальної роботи, Інститут людини Київського університету імені Бориса Грінченка, бульвар Ігоря Шамо, 18/2, м. Київ, Україна, 02000

ORCID: 0000-0002-9067-4820

Бібліографічний опис статті: Дуля, А. (2021). Соціально-психологічний портрет учасників ATO/OOC. Ввічливість. Humanitas, 5, 19-23, doi: https://doi.org/10.32782/humanitas/2021.5.3

\section{СОЦАЛЬНО-ПСИХОЛОГІЧНИЙ ПОРТРЕТ УЧАСНИКІВ АТО/ООС}

У статті представлені результати дослідження актуальних проблем учасників АТО/ООС. Особлива увага приділена вивченню психоемоційного стану учасників АТО/ООС, їхніх типових поведінкових, фізичних, емоційних реакиій та особливостей мислення після повернення із зони проведення бойових дій.

Охарактеризовано вплив типових реакцій учасників АТО/ООС на адаптацію до мирного життя та на членів їхніх сімей. Визначено рівень стресу та тривоги в учасників АТО/ООС та чинники їх виникнення. Розкрито сутність посттравматичного стресового розладу в учасників АТО/ООС.

Визначено, що учасники АТО/ООС - цее особлива група отримувачів соціальних послуг, які, безумовно, є захисниками нашої батьківщини, але також є особами, на життя яких суттєво вплинули бойові дії. У зв'язку з тривалим перебуванням у небезпечних для життя $і$ здоров'я умовах в учасників АТО/ООС, які повертаються додому, можуть спостерігатися порушення соціальної взаємодї, замкнутість, соціальна ізоляція, втрата інтересу до сімейного та суспільного життя, переживання негативних емоцій, емоційна нестабільність, підвищення рівня агресивності, роздратованості, надмірне вживання алкогольних або психотропних речовин. Відносини учасників АТО/OОС із найближчим оточенням та суспільні взаємовідносини стають більш напруженими та конфліктними. У них можуть виникати суперечки та конфліктні ситуації в сім'ї на робочих місиях, у транспорті, в різних установах, куди вони звертаються за допомогою в оформленні документів на отримання соціального статусу та пільг, різних видів соціальних послуг.

Перспективними дослідженнями у изьому напрямі автор вбачає подальше розкриття ознак посттравматичного стресового розладу серед учасників АТО/ООС та визначення шляхів соиіальної адаптації та реабілітації иісї групи отримувачів сочіальних послуг.

Ключові слова: бойові дї̈, учасники АТО/ООС, поведінкові реакції, емоційні реакції, фізичні реакції, посттравматичний стресовий розлад.

\section{Alina DULIA}

Lecturer at the Department of Social Pedagogy and Social Work, Institute of Human Sciences of Borys Grinchenko Kyiv University, 18/2 I. Shamo Boulevard, Kyiv, Ukraine, 02000

ORCID: 0000-0002-9067-4820

To cite this article: Dulia, A. (2021). Sotsialno-psykholohichnyi portret uchasnykiv ATO/OOS [Socio-psychological portrait of ATO/OOS participants]. Vvichlyvist. Humanitas, 5, 19-23, doi: https://doi.org/10.32782/humanitas/2021.5.3

\section{SOCIO-PSYCHOLOGICAL PORTRAIT OF ATO/OOS PARTICIPANTS}

The article presents the results of the study of current problems of ATO/OOS participants. Particular attention is paid to the study of the psycho-emotional state of the participants of the ATO/OOS, their typical behavioral, physical, emotional reactions and peculiarities of thinking after returning from the combat zone.

The influence of typical reactions of ATO/OOS participants on adaptation to peaceful life and on their family members is characterized. The level of stress and anxiety in the participants of the ATO/OOS and the factors of their occurrence are determined. The essence of post-traumatic stress disorder in ATO/OOS participants is revealed.

It is determined that the participants of the ATO/OOS are a special group of recipients of social services, who, of course, are the defenders of our homeland, but also persons whose lives have been significantly affected by hostilities. Due to the prolonged stay in dangerous to life and health conditions, the participants of the ATO/OOS who return home may experience violations of social interaction, isolation, social isolation, loss of interest in family and social life, experiencing negative emotions, emotional instability, increased levels of aggression, irritability, excessive alcohol or 
other psychotropic substances. Relations between ATO/OOS participants and their immediate environment and social relations are becoming more tense and conflicted. They can cause disputes and conflict situations in the family at work, in transport, in various institutions, where they apply for help in obtaining documents for social status and benefits, obtaining various types of social services.

The author sees promising research in this direction in the further disclosure of signs of post-traumatic stress disorder among the participants of the ATO/OOS and identification of ways of social adaptation and rehabilitation of this group of recipients of social services.

Key words: combat actions, participants of anti-terrorist operation/environmental protection, behavioral reactions, emotional reactions, physical reactions, post-traumatic stress disorder.

Постановка проблеми. Військові дії, які розгортаються на сході України, стали для учасників АТО/ООС стресовою подією, яка негативно впливає на їхнє фізичне та психологічне здоров'я. Військовослужбовці виявляються не підготовленими до небезпечних та екстремальних умов війни, що впливає на зміну їхнього психоемоційного стану, порушення психічних і поведінкових реакцій. В умовах війни зростає вплив психотравмуючих чинників, які піддають психіку військовослужбовців серйозним якісним змінам і можуть набувати як чітко виражених форм чи бути прихованими, відстороненими в часі реакціями. Вони можуть проявитися в розладах психічної діяльності, а також неможливості адаптуватися в мирному житті після повернення із зони АТО/ООС.

Аналіз дослідження. Проблеми ветеранів АТО/ООС та наслідки бойових психічних травм висвітлені в працях Г. Акімова, В. Березовець, О. Мраморнова, О. Лобастова, В. Попова, П. Сидорова, В. Стасюк, О. Харченко. Грунтовні напрацювання щодо проблеми посттравматичного стресового розладу серед учасників бойових дій представлені в низці досліджень зарубіжних учених (М. Брікелл, Д. Вінгард, Р. Гіссер, Д. Критц-Сільверстейн, Н. Левін, М. Райан, М. Рассел, Дж. Салліс, Д. Слімен, Т. Сміт, Т. Шрагай, С. Шрейбер). Теоретичні надбання вищезгаданих авторів становлять наукову базу для вивчення типових фізичних, емоційних та поведінкових реакцій учасників ATO/OOC, чим займались українські дослідники О. Вогнесенська, Т. Майстренко, М. Мушкевич, Г. Циганенко, О. Буковська.

Метою дослідження $є$ висвітлення й аналіз результатів дослідження психоемоційного стану, типових реакцій та особливостей мислення учасників АТО/ООС після повернення із зони бойових дій.

Виклад основного матеріалу. Військовослужбовці, чиї спеціалізовані професійні обов'язки зумовлюють особливий ряд прав і виключні засоби захисту, становлять особливу групу громадян. Адже за своїм змістом професійна діяльність військовослужбовців має певні характерні особливості, а саме: наявність ризику для життя; чітка регламентація правил, професійних обов'язків та часу виконання доручень; можливість застосування насильницьких дій (іноді 3 використанням зброї) у процесі виконання закріплених законом функцій; відсутність звичних умов життя; звуження кола людей, з якими спілкуються військовослужбовець і його сім'я (Олексюк, 2011). Таким чином, специфіка професійної діяльності військовослужбовців, наявність тих чи інших індивідуальних особливостей, типу характеру відбивається на житті військовослужбовця та на життєдіяльності їхніх сімей.

Перебуваючи в зоні бойових дій на сході України, військовослужбовці можуть зустрітися зі значною кількістю травматичних факторів, які в подальшому житті можуть призвести до порушення психоемоційної сфери та фізичного здоров'я, а саме: обстріл ворога; потрапляння в засідку або полон до ворога; перебування в незнайомому місці та серед вороже налаштованого місцевого населення, що може серйозно ускладнити його життя; новини про загибель або травмування товаришів; мертві тіла або частини тіл як норма навколишнього оточення; отримання значних травм від бомб, мін або інших вибухових пристроїв (Мушкевич, 2015).

Як наслідок перебування в зоні бойових дій $є$ ймовірною загрозою, що після повернення учасника ATO/OOC до мирного життя він сприйматиме навколишне середовище крізь «військову призму дійсності». В учасників АТО/ООС можуть проявлятися замкнутість, соціальне дистанціювання від оточення, низький рівень соціальної активності, переживання негативних емоцій, відсутність емоційного контакту між членами родини, тривога щодо зміни ставлення сім'ї до нього, відчуття страху за свою сім'ю та невпевненості у своєму 
майбутньому. Також в учасників бойових дій можуть спостерігатися прояви агресивності, роздратованості, надмірне вживання алкоголю або інших психоактивних речовин, конфліктності на робочих місцях, у транспорті, в різних установах, куди вони звертаються за допомогою в оформленні документів та отриманні соціальних послуг.

Після повернення учасників АTO/OOC iз зони бойових дій їм потрібно повертатися і до мирного життя. Це виявляється непросто, і їм потрібен час, щоб соціалізуватися та адаптуватись до нових умов життя. Учасники АТО/ OOC, які повертаються із зони бойових дій, - це вже інші люди, які отримали унікальний досвід життя, як позитивний, так і негативний. Вони мають інші думки, погляди на життя, знайомства, проблеми, страхи, поведінку, а також інший емоційно-психологічний стан. Їх не полишають спогади про побратимів та події, які трапилися з ними під час перебування в зоні бойових дій (Устінова, Глазкова, Донець, 2020).

3 метою дослідження психоемоційного стану, поведінкових та фізичних реакцій, наявності проявів ПТСР в учасників бойових дій після повернення додому було проведено скринінг емоційних переживань та фізичного здоров'я часників АТO/OOC (за методикою Refugee health screener - 15 (RHS-15) (Refugee health screener, 2012). RHS-15 - це інструмент діагностики особливостей переживань та стану психічного здоров'я. Запитання скринінгу було адаптовано під індивідуальні особливості цільової групи - учасники ATO/OOC. Опитувальник включає питання щодо: поведінкових, емоційних, фізичних реакцій та особливостей мислення в учасників АТО/OОС, які повернулися додому із зони бойових дій; рівня їх соціальної адаптації та інтеграції до цивільного життя; проявів симптомів посттравматичного стресового розладу. Також респондентам було запропоновано визначити свій рівень напруги, стресу та тривоги за допомогою термометру стресу. В опитуванні взяло участь 18 учасників ATO/OOC у перші місяці після повернення додому. Дослідження проводилось у рамках виконання наукової теми Інституту людини Київського університету імені Бориса Грінченка «Особистість в умовах суспільних трансформацій сучасної України» (державний реєстраційний номер 0110U002960).
У процесі дослідження ми визначили, що більшість (74,5\%) учасників АТО/ООС повертаються додому із переоцінкою цінностей життя та змінами в типових реакціях особистості. В учасників бойових дій змінюється думки, погляди на життя, поведінка; можуть проявлятися імпульсивність, емоційна нестабільність, неконтрольована агресія, апатія, відсутність бажання займатися побутовими речами та хобі. Також в учасників ATO/OOC, які пережили жахливі події війни, можуть проявлятись депресивні стани. Вищезазначене свідчить, що в учасників ATO/OOC наявні типові реакції учасників бойових дій, а саме:

- емоиійні реакиії: емоційна нестабільність, нервовість, поганий настрій - 61,11\%; роздратованість $-72,2 \%$; пригнічений стан $-11,1 \%$. Більше 33,3\% опитаних зазначили, що відчувають емоційну порожнечу (відчуваєте печаль, але не можете плакати, не в змозі переживати ніжні почуття), це може бути спричинене тим, що в екстрених умовах війни учасники АТО/ООС відключають свої емоції, адже в бою вони відволікають, військовослужбовці мають загострити всі свої органи почуттів, але не мають проявляти або загострювати свої емоції. Тобто розум, очі, слух, шкіра повинні працювати, а емоції - ні. Це правило війни учасники АТО/OOC часто практикують і вдома після повернення із зони бойових дій;

- поведінкові реакиії: негативні почуття, спалахи гніву та часто неконтрольована агресивна поведінка, паніка, страх - 44,4\%, замкнутість та відсторонення, надмірне вживання алкоголю - 12,8\%. Більше ніж 6,6\% респондентів зазначили, що в них $є$ відчуття тривоги, хвилювання та готовність діяти, захисні інстинкти (здригається і лякається, наприклад, коли хтось підходить ззаду, чує голосні звуки, вибухи салюту, при великих скупченнях людей). Отримані дані засвідчують, що в перші дні після отримання учасниками АТО/OОС бойової травми вони перебувають на стадії бойової тривоги, яка є «закликом до бою», активізацією всіх захисних механізмів організму;

- фізичні реакиї: $33,3 \%$ опитаних учасників АТО/ООС зазначили, що відчувають сильну фізіологічну реакцію (пітливість, прискорене серцебиття), згадуючи про травматичні події, які трапилися на війні, 38,8\% вона турбує досить сильно. В учасників АТО/OOC спостерігається безсоння, головний біль, запаморочення, 
слабкість, переднепритомний стан $(38,8 \%)$. Bci опитані учасники ATO/OOC зазначили, що в перші тижні після повернення додому в них спостерігаються болі в м'язах, кістках, суглобах.

Чинниками вищезазначених реакцій в учасників ATO/OOC є зовнішні або внутрішні стресори, які можуть повертати учасників бойових дій у минуле, в умови війни, порушувати фізичне та психологічне здоров'я та викликати стрес-реакцію.

Окрім типових реакцій, в учасників ATO/ ООС ще спостерігаються зміни в мисленні: часті думки про війну та про побратимів (33,3\%); відчуття безпорадності $(26,67 \%)$; гостре реагування на несправедливість $(11,1 \%)$. Також нами було визначено, що 33,3\% учасників АТО/ООС із числа опитаних досить сильно переживають травматичну подію, реагують і почуваються так, ніби це трапляється з ними знову.

В учасників ATO/OOC також спостерігається відчуття суму за побратимами та докори сумління, що вони повернулися додому, а їхні побратими залишилися воювати $(44,4 \%)$.

Майже $38,8 \%$ опитаних зазначили, що ніхто $з$ членів їхньої сім'ї не розуміє та й не може зрозуміти, адже вони не були поруч із ним і не мають досвіду участі в бойових діях. Учасники АТО/OOC намагаються закритись та відсторонитись від членів сім'ї, шукаючи підтримку в побратимів. Відсутність в учасників АTO/OOC бажання безпосередню брати участь у сімейному житті, вирішувати особисті

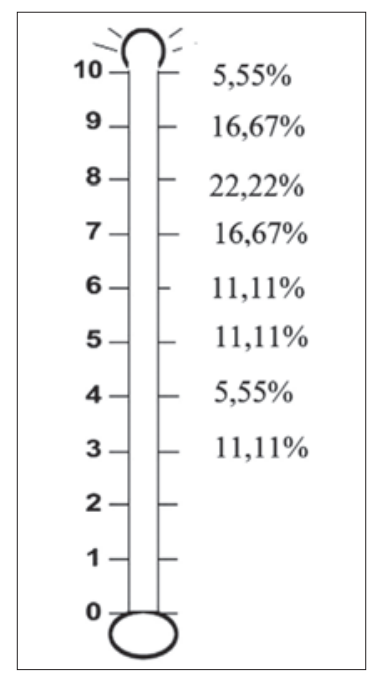

Рис. 1. Рівень стресу та тривоги в учасників АTO/ ООС відповідно до термометра стресу та сімейні проблеми призводить до суперечок та конфліктів у сім’і та бажання повернутися в зону бойових дій.

Досліджуючи рівень напруги, тривоги та стресу в учасників бойових дій, використовуючи термометр стресу, ми з'ясували, що 72,2\% опитаних учасників ATO/OOC у перший тиждень після повернення додому відчували прояви напруги та сильного стресу із позначкою від 6 до 10, а в 27,7\% рівень стресу сягав позначки від 1 до 5 (див. рис. 1).
Високий рівень стресу і тривоги спричинений через невпевненість у майбутньому та неможливість швидкого адаптування до мирного життя, проблеми 3 фізичним здоров'ям, труднощі у спілкування з рідними, нерозуміння рідними досвіду, який пережив учасник АTO/OOC, труднощі в оформленні статусу «учасник бойових дій» та соціальних пільг як учасників АТО/OOC, матеріальні проблеми та труднощі в професійній адаптації, суперечки та конфлікти в сім'ї, на роботі. Також опитані учасники ATO/OOC зазначили, що відчувають роздратування через складність та заплутаність процедури оформлення соціального статусу та пільг, неприйняття їх суспільством та стереотипне ставлення громадськості.

Деякі учасники ATO/OOC (16,67\%) зазначили, що в них є страх за членів своєї родини, адже вони інколи гостро переживають травматичну подію, в них відбуваються флешбеки.

Отже, якщо в учасників АTO/OOC тривалий час після повернення із зони бойових дій наявні вищезазначені прояви фізичних, емоційних та поведінкових реакцій, і вони мають труднощі в процесі самостійної адаптації до мирного життя - це може свідчить про посттравматичний стресовий розлад.

На відміну від гострої стресової реакції, посттравматичний стресовий розлад виникає не під час травмуючої події, а у віддалені терміни - після виходу людини зі стану найтяжкого стресу. Латентний період становить, як правило, 2-6 місяців із моменту отримання психологічної травми.

Посттравматичний стресовий розлад - це непсихотична відстрочена реакція на травматичний стрес, здатна викликати низку психічних і поведінкових порушень.

Психологічні наслідки участі в бойових діях призводять до того, що в умовах вже мирного часу через загострене почуття справедливості, підвищену тривожність, «вибухові» реакції, що періодично виникають у відповідь на будь-які подразники, депресивні стани, в учасників АТО/ООС порушується соціальна взаємодія, виникають сімейні конфлікти та проблеми з працевлаштуванням. У таких людей втрачається інтерес до суспільного життя, знижується активність у процесі вирішення життєво важливих проблем 
(Посттравматичний стресовий розлад у військовослужбовців, 2019).

Отримані результати свідчать, що майже в усіх учасників АТО/ООС спостерігаються вищезазначені реакції учасника бойових дій, але більшість учасників АТO/OOC, які є психологічно сильними особистостями, протягом кількох місяців можуть самостійно адаптуватися до мирного життя. Але залишається певна кількість учасників АTO/OOC, які не можуть самостійно адаптуватися і потребують професійної допомоги в соціальній адаптації та інтеграції.
Висновки. Отже, через типові поведінкові, емоційні та фізичні реакції учасники АТО/ООС стикаються із труднощами під час самостійної адаптації до мирного життя та налагодження внутрішньосімейної взаємодії. Загострення цих реакцій може спричинити виникнення в учасників $\mathrm{ATO} / \mathrm{OOC}$ посттравматичного стресового розладу.

Перспективи подальших досліджень вбачаємо в подальшому дослідженні ознак посттравматичного стресового розладу серед учасників АТО/ООС та визначенні шляхів соціальної адаптації та реабілітації цієї цільової групи.

\section{ЛІТЕРАТУРА:}

1. Буковська О.О. Психологічна допомога сім'ям військовослужбовців, які повертаються із зони бойових дій. Вісник Чернігівського наџіонального педагогічного університету. Серія: Психологічні науки. 2015. Вип. 128. С. 29-32.

2. Мушкевич М. Волинь: як допомогти військовому та його сім'ї реабілітуватися. Волинські новини. URL: https://www.volynnews.com/news (дата звернення: 20.11.2021).

3. Олексюк Н.С. Соціально-педагогічна робота з сім'ями військовослужбовців в умовах реформування Збройних сил України : монографія. Київ : Видавничий дім «Слово», 2011. 304 с.

4. Посттравматичний стресовий розлад у військовослужбовців - учасників бойових дій. КПН Сумської обласної ради. URL: https://narkosumy.lic.org.ua (дата звернення: 13.11.2021).

5. Повернення із зони бойових дій: пам'ятка для сімей військовослужбовців, які повернулися 3 зони АТО / ред. Т.М. Майстренко. Житомир : ФОП Євенок О.О., 2015. 30 с.

6. Устінова Т., Глазкова А., Донець Ю. Батьки повертаються з війни: Розповідь про сімейне відновлення. Київ : ТОВ «Мега-поліграф» 2020. 64 с.

7. Refugee health screener - 15 (RHS-15). Pathways to Wellness: Integrating Refugee Health and Well-Being. URL: https://x9yjk2t419ghu7ty7bhu81 ac-wpengine.netdna-ssl.com/wp-content/uploads/2012/09/RHS15_Packet_Pathw aysToWellness-1.pdf (date of access: 08.06.2021).

\section{REFERENCES:}

1. Bukovska, O.O. (2015). Psykholohichna dopomoha simiam viiskovosluzhbovtsiv, yaki povertaiutsia iz zony boiovykh dii [Psychological assistance to the families of servicemen returning from the combat zone]. Visnyk Chernihivskoho natsionalnoho pedahohichnoho universytetu. Seriia: Psykholohichni nauky - Bulletin of Chernihiv National Pedagogical University. Series: Psychological Sciences, 128, $29-32$ [in Ukrainian].

2. Mushkevych, M. (2015). Volyn: yak dopomohty viiskovomu ta yoho simi reabilituvatysia. [Volyn: how to help the military and his family to rehabilitate]. Volyn news. Retrieved from: https://www.volynnews.com/news [in Ukrainian].

3. Oleksyuk, N. S. (2011). Sotsialno-pedahohichna robota z simiamy viiskovosluzhbovtsiv v umovakh reformuvannia Zbroinykh Syl Ukrainy. [Socio-pedagogical work with the families of servicemen in the conditions of reforming the Armed Forces of Ukraine]. Kyiv: Slovo Publishing House [in Ukrainian].

4. Posttravmatychnyi stresovyi rozlad u viiskovosluzhbovtsiv - uchasnykiv boiovykh dii [Post-traumatic stress disorder in servicemen - participants in hostilities]. KPN of the Sumy regional council. Retrieved from: https://narkosumy. lic.org.ua [in Ukrainian].

5. Maistrenko, T.M. (Eds.). (2015). Povernennia iz zony boiovykh dii: pamiatka dlia simei viiskovosluzhbovtsiv, yaki povernulysia z zony ATO [Return from the combat zone: a reminder for the families of servicemen who returned from the anti-terrorist operation zone]. Zhytomyr: FOP Evenok OO [in Ukrainian].

6. Ustinova, T., Glazkova, A., \& Donets, Y. Batky povertaiutsia z viiny: Rozpovid pro simeine vidnovlennia [Parents return from the war: A story about family recovery]. Kyiv: Mega-Polygraph LLC [in Ukrainian].

7. Refugee health screener - 15 (RHS-15). Pathways to Wellness: Integrating Refugee Health and Well-Being. Retrieved from: https://x9yjk2t419ghu7ty7bhu81ac-wpengine.netdna-ssl.com/wp content/uploads/2012/09/RHS15_ Packet_Pathw aysToWellness-1.pdf [in English]. 